\title{
Values Education or Religious Education? An Alternative View of Religious Education in the Secular Age, the Case of Turkey
}

\author{
Muhammet Fatih GENÇ(D) \\ Religious Education Department, Kocaeli University, Umuttepe Kampüsü, İzmit.Kocaeli 41380, Turkey; \\ muhammetfatih@hotmail.com; Tel.: +90-262-303-4701
}

Received: 15 November 2018; Accepted: 12 December 2018; Published: 19 December 2018

\begin{abstract}
Debates about the teaching of religion date back to the formation of the modern education system, when religion was first compartmentalized as a distinct subject within a broader curriculum. In many places, they continue to rage today. In Turkey, they are inextricably tied to the creation of the country's system of secular public instruction in the 1920s and the transition to multi-party government in the 1940s. On 30 March 2012, Turkey passed a new law that revamped the country's public educational system, mandating twelve years of instruction divided into three four-year periods (roughly corresponding to elementary, middle, and high school). This law led to the opening of many new religious schools—-known as Imam-Hatip schools (i.e., schools for the training of imams and hatips, or preachers) - across the country, especially at the middle-school level. The number of students studying in these schools rose from 70,000 in 2002 to 1,300,000 after the new law. New elective courses on religion were also added to the curriculum, and curricular and extra-curricular religious-education activities offered by government-sponsored Islamic civil society organizations became more prevalent. All of this has reignited old debates about religious instruction in the country. This article begins with an overview of the history of secularism in Turkey. It then focuses on the history of religious education and the model of religious education in Turkey. It concludes with a discussion of how religious education centering on values education operates within the secular framework of public education in confessional and non-confessional formats.
\end{abstract}

Keywords: secularism; religious education; values education

\section{Introduction}

Debates about the teaching of religion in Turkey date back to educational reforms in the Ottoman Empire in the nineteenth century. Prior to the opening of Western-style schools during the Tanzimat era (1839-1876), education in the country was offered in madrasas, where all education was more or less religious in nature. In the new Western-style schools, however, religion became only a part of a broader curriculum [1].

From the Tanzimat era to the establishment of the Republic of Turkey in 1923, religious education remained part of the general education offered in Western-style schools and continued to dominate the education offered in madrasas. During this period, in other words, institutions offering traditional religious-based education and those offering modern secular education coexisted.

The collapse of the Ottoman Empire and the establishment of the Republic of Turkey brought about perhaps the most spectacular development in the history of Islamic education. The declaration of the new republic was more than a political event; it was also a social, cultural, and economic revolution, and one in which secularism emerged as a central concept. The boundary between religion and politics in Turkey was drawn in terms of secular principles: the separation of state and religion, and the 
separation of religion from educational, cultural, and legal affairs. This meant the independence of thought and independence of institutions from the dominance of religious thinking and religious institutions. The major reforms of the era were closely connected with secularism. For a quarter century, the Turkish educational system worked on a strictly secular basis; all levels of religious education were officially banned in schools. In this era, Turkey turned its face to the West by adopting Western laws, including the Italian Penal Code and the Swiss Civil Code, and implementing Western policies while establishing its institutions and laws.

In 2002, when the Justice and Development Party (Adalet ve Kalkınma Partisi, hereafter AKP) came to power, there was at first a rapid secularization. But after 2012, the secular emphasis of the party started to decrease. In this process, important developments also took place in the field of religious education. Despite the state's official support for religious education, increasing numbers of young people in Turkey embrace atheistic and "deistic" stances toward religion [2,3].

\section{The History of Secularism in Turkey}

The state and society both experienced a number of dramatic changes during the final decades of the Ottoman Empire and the early decades of the Republic of Turkey. The state transitioned from a large and diverse empire in which religion played an important role into a much smaller, less diverse, and strictly secular republic. These drastic changes resulted in social polarization and conflicts between different ideologies and political views. The consequences of these changes are still being felt not only in Turkey but also in other Muslim countries that went through a similar transition in the last century [4].

The new Turkish state-following the teachings of its founding father, Atatürk-took a strict form of secularism, laicism, as its main ideology. It sought to use this ideology both to modernize the state and society and to purge them of religious dogma, superstition, and ignorance [5].

\subsection{Strict Secularism (1923-1946)}

Under Atatürk, Turkey implemented radical reforms that targeted both the state structure and social life. These included the abolition of the sultanate in 1922, followed shortly after by the declaration of the republic in 1923. In the following years, the caliphate was abolished, all religious-spiritual orders were banned and closed, and the article declaring Islam as the state religion was removed from the constitution, eventually replaced with an article declaring the state to be secular in character. In time, reciting the Qur'an in its original Arabic was banned, and Turkish was mandated as the sole language for all prayers and religious rituals [4].

\subsection{Liberalization of Secularism (1946-2002)}

After a long period of state pressure and strict limitations on religious practices, things started to change in the late 1940s. This did not mark a return to Ottoman-era practices or a re-Islamization of society but rather a liberalization of the country's secular regime. Though Islam continued to be practiced in Turkey, even during the early non-tolerant secularist era of the state, the religion became increasingly significant toward the end of the 1940s [6] (p. 11).

Turkey was run under the single-party rule of the Republican People's Party (Cumhuriyet Halk Partisi, hereafter CHP) until 1940 and had its first multi-party election in 1946, an election that was suspiciously won by the CHP, the single party in charge since the beginning of the republic. Although the party won the first multi-party elections, they realized the extent of the social discomfort that had accrued over the years and decided that they would have to take steps toward addressing some of the public's demands, such as offering elective religious education in schools and establishing a faculty of theology at the university level. Most of these steps were accepted as measures to maintain control of religious education and to avoid the potential radicalism and fanaticism of religious services provided by private parties. The following elections held in 1946 were won by the Democratic Party (Demokrat Parti, hereafter DP) at the end of a campaign that focused on discrimination and human rights abuses 
resulting from the constraints the secular state placed on religious practices in the government and the society. On its first day in government, the DP rescinded many bans, allowing prayers and the call to prayer to once again be performed in the Arabic language. The DP also established more religious schools (Imam-Hatip schools) and several faculties of theology at different universities [7] (p. 33).

Turkey is a county where a majority of the population identifies as Muslim and has strong ties to Islamic culture. However, Turkey is by law also a secular state, which conflicts with its Islamic nature. Besides Islam and secularism, nationalism and democracy are two other major concepts that represent the character of the country [8] (pp. 3-14).

\subsection{Decline of Secularism 2002-Present}

Since the DP in the 1950s, and especially under the AKP today, religion has been abused for political ends. However, the state remains staunchly secular [9] (p. 27). This is because secularism was inscribed in the constitution and protected by the military as well. Therefore, secularism remained powerful at the state level until the end of the 1970s. The army has intervened via coups or other means several times since the 1970s, banning Islamist parties and individuals from being active in the parliament or in society. Nevertheless, the public perception increasingly leaned toward Islamists, or more conservative movements in general. The AKP, following this social tendency toward being both conservative and "Westernized and moderate", came to power in 2002 [10].

When the AKP came to power, it faced the challenge of how to rule a country in which multiple identities, ideologies, and understandings of secularism coexisted. One approach to secularism, still practiced by militant secularists, has evolved into something akin to a political religion for its followers. The Kemalist elites believe that secularism is the sole path to Turkish development. They also believe that Islam is primarily an ideology, a political religion, rather than a faith like Christianity, and that it thus needs to be kept separate and apart from all state institutions. Yet at the same time, the Kemalist state continued to provide religious services in order to maintain control over peoples' perception of Islam and to prevent it from being politicized. As a result of this approach, secularism has evolved into an ideology not of "freedom of religion" but rather "freedom from religion". The signs of this secularism include the ban on headscarves in government places, including schools, and abolishing Islamist political parties. A second approach to secularism is a more moderate one, one that considers Islam as a part of Turkish people's lives and believes that the state should provide services to fulfill people's demands on religious affairs. Adherents of this approach believe that the state Religious Affairs Office (Diyanet İşleri Başkanlığı, hereafter DIB) should be more active. According to them, religion and politics should not be two sharply separated spheres. For them, religion promotes dialogue and tolerance and can be utilized as a core element to bring the society together. There is also a third approach, represented by a small group of libertarians who claim that politics should be completely free from religion and that the state should have no relation with religion. Among these three approaches, that of the AKP, though this has changed over time, is closest to the second one [6] (pp. 21-22).

The AKP, under its leader Recep Tayyip Erdoğan (who also graduated from an Imam Hatip School), has been successful in politics with its approach, which it identifies as "conservative democracy". The party increased its popularity in successive elections as it worked to modify institutions and the state legislative structure to better comply with European Union standards. Even though it has tended to embrace an Islamic-oriented agenda in its later terms (so called Neo-Ottomanism), it has managed to retain popular support and continues to Islamize the country.

In Turkey, political Islam has been represented by two major groups. The first of these was the National Outlook Movement (Milli Görüş, MG), led by Necmettin Erbakan, who was accused of attempting to convert the governmental system to sharia and whose political parties were therefore banned several times. The current political party of the MG is the Felicity Party (Saadet Partisi), which only represents a very small percentage of the electorate. It is known as anti-Western and blames Western countries for being the major cause of the problems in the Islamic world. The other group is 
the current AKP, and its leader Recep Tayyip Erdoğan, which came to power as a moderate party open to the West and to developing better standards in human rights and democracy. The AKP proposes that Islamic civilization can be established while living a Western way of life. It also emphasizes that its understanding of secularism is quite different from that of the Kemalists [11].

Secularism in Turkey has been utilized both to create a national identity and to impose the state's authority over monarchists and the radical religious establishment, similar to "laicism" as practiced in France [12,13]. But its application in Turkey took the form of a top-down ideology dictated by the state [14]. According to Toprak (1981), "Turkey is a 'semi-secular' state because it embraced state supervision of religious organizations and religious activity, a stance which is not compatible with the traditional Western understanding of secularism. Religion and religious institutions were generally represented as obstacles to innovation and national progress. Thus, rationalism rather than religion has been embraced as the basis of law, education, and politics" [7] (p. 47). In recent years, however, the number of religious schools has increased tremendously across the country, and the DIB has gained extra privileges in many areas and is granted very high budgets. All of this indicates that secularism is losing its hegemony in the state and also in the public sphere. However, over the sixteen years that it has been in power, the AKP has been mostly pragmatic on the issue of religion and insists the country will remain secular.

\section{Religious Education between 1923 and 1980}

Under the republic, a number of changes were introduced that affected the education system. On 3 March 1924, a new law on the unification of education came into force. This law closed all of the madrasas and attached all educational institutions and the entire budget for education in Turkey to the Ministry of National Education [15]. This law also placed Qur'anic and religious education in the curriculum of all state schools, starting at the second grade of elementary school. To train religious scholars to teach such classes, a faculty of theology was established. In addition, to meet the demands of the public, religious vocational high schools (Imam-Hatip schools) were opened. Religious instruction in the early years of the republic aimed at supporting the state's modernization activities and correcting popular "misinterpretations" in the area of religion. The first manner of application unfortunately was not able to last, and later it caused the start of a problematic period (1924-1948) in terms of education of religion $[16,17]$.

The first negative development in the education of religion started in 1926. At that time, the length of religious courses was one hour in the curriculum of the third, fourth, and fifth grades of elementary school. On November 30, 1929, the Board of Education and Discipline of the Ministry of National Education decided to limit religion classes to an elective class not subject to examination in urban elementary schools. In a decision a year later, religion classes were further reduced to a mere thirty minutes of elective instruction per week, and only for students in the fifth grade [18] (pp. 616-620).

Religious education was removed from rural schools in 1927 and from all schools in 1936. However, it continued on in extra-curricular form in rural elementary schools until 1938. In 1939, a new regulation removed religious education from the curriculum entirely. In the program-development activities started after 1927, religious education was removed from high schools, and between 1929 and 1931 it was gradually removed from teacher-training schools as well [18] (p. 616).

Following this process of eliminating religious education from the educational system, Imam-Hatip schools were closed in 1929, and the faculty of theology in what is today Istanbul University was closed in 1933. In the years that followed, there was no institution providing education in religion or any religious subject [19] (p. 107).

The removal of religious education and the institutions providing that education from the public education system had tragic results. Discussions in the seventh CHP congress in November 1947 are interesting in terms of reflecting the situation that resulted from the absence of religious education in the intervening years. This congress was a turning point for religious education in Turkey. At the congress, the CHP deputy from the city of Sinop, Vehbi Dayıbaş, stated the complaints of voters as 
follows: "Christians go to church and pray there but what will our children do and how are they going to pray? They are lacking of vital religious knowledge! For that reason, I think that instruction in religion should be given". Abdulkadir Güney, representative from Çorum, offered a similar assessment: "According to analyses that we have done, it is clear that those nations who support their religion have always been pioneers in social development; those who do not care about their religion have remained undeveloped. While all the world's nations appreciate our religion and its holy book, the Qur'an, why do we ignore our religion's development?" By asking such questions, Güney expressed the results of depriving students of religious education [17] (p. 108). Sinan Tekelioğlu, a deputy from Seyhan, offered the following words in his speech at the congress: "Christian, Jewish, and Turkish sects have opened schools for themselves and raised their priests there! Let me tell you what I heard from the villagers! They don't have anyone to bury their dead. Today, gambling and drinking alcohol are at an unbelievably high level. There is no fear of God in this faithless country. There is no respect for father, mother, or elderly people. When they are asked, 'Who is God?', children cannot give any answer; they don't know their God!" Similar complaints were expressed in 1948 in the journal Selamet Mecmuast by the editor of the Cumhuriyet newspaper Nadir Nadi. He complained about the lack of imams and muezzins in villages and mosques [20] (p. 457).

After these quarrels in 1948, religious education was reintroduced to primary schools, but in the form of an extra-curricular lesson. One hour "elective" religious-education lessons were introduced at the fourth- and fifth-grade levels. Families who wanted their children to take these lessons were required to submit a special petition to school authorities. In addition, in 1949, the Ankara University Faculty of Theology was opened, and later, in 1951, Imam-Hatip schools were opened again [21] (pp. 218-219).

In 1950, a new government was elected in nationwide multi-party elections. This new government was more sympathetic to the religious sentiments of society and introduced a religion course at the high-school level. This time, students were automatically enrolled in the course. If the parents wanted to exempt their children from the course, they had to apply to the school with a written request. Religious education thus once again found its way into the state curriculum [22] (p. 128).

In 1967, a religion course was introduced in the first and second years of high school. Students, however, were only enrolled in the course at the written request of their parents. In 1975, the course was extended to the third and final year of high school. This optional religious education in schools continued up to 1982 [23] (pp. 75-77). Thus it was that during this period (1948-1982), religious education remained optional until the 1980s, while an ethics and character-education course was compulsory in schools. Before 1980, religion and ethics courses were two separate courses. Religion courses were based on the confessional religious-education model, while ethics courses were fully secularized and there was no reference to religion [22] (pp. 151-153).

\section{Religious Education between 1980 and 2012}

Until the military coup of September 12, 1980, religion courses were elective. The period immediately prior to the coup was a time of acrimonious public debate, social and ideological conflict, and violent clashes between left- and right-wing groups. In the wake of the coup, the military administration sought to restore order by arresting hundreds of thousands of people and executing dozens more [22] (p. 252). It also issued a new constitution which, among other things, made religious education mandatory in Turkey's schools-a move it viewed as a necessary step toward remedying the social unrest of the previous decade by re-unifying the nation's values [24] (p. 146).

This new mandatory religious education, in the form of a new class dubbed Religious Culture and Ethics (Din Kültürü ve Ahlak Bilgisi), was codified in the twenty-fourth article of the 1982 Constitution, which stated that "education and instruction about religion and ethics is provided under the supervision of public agencies. The related course is one of the mandatory courses delivered at the basic education level and secondary education level. The other related educational and instructional activities are provided only upon request of people, and for young people, of legal guardians" [25] 
(p. 5). These new classes were to be taught for two hours a week, from fourth grade in elementary school through the end of middle school, and one hour a week through high school [26].

Unlike the elective Islamic courses of earlier periods, the post-1982 Religious Culture and Ethics lessons were designed as classes that would foster knowledge about, and unity in, a diverse society. An important voice behind this new class was the professor Beyza Bilgin, who argued that compulsory religious education was necessary to foster harmony among Turkey's various religious sects. The very title of the class, in the form of "religious culture and ethics", would be broad enough to encompass every sect in the country, and this inclusiveness would prevent conflict, support social unity and solidarity, and at the same time instruct pupils about the facts of society [23] (pp. 66-81). In line with this aim, the class needed to be taught based on a non-confessional model that could meet the demands of society.

The result was a class on religious culture and ethics that was not exclusively about Islam. Instead, it provided information about religion in a more general sense, though with an Islamic focus. Bilgin argues that "the reason for this course as a mandatory course ... is to provide general information about Islamic religious and ethics culture" [23] (pp. 66-70). This model was the result of Turkey's historical experience of religious education. The course was designed based on an integrated model of religious education aiming at fostering social unity by exposing students to, and promoting respect for, the reality of difference in society.

The Turkish Ministry of National Education sums up its approach in designing the class as follows: "In determining the content of the course of religious culture and ethics, an approach centered on basic religious assumptions that are beyond any religious movements (neutral to all religious movements and without any discussion of them) has been adopted. The purpose of this program is to inform students about religion and ethics, to improve their related skills, and thereby to contribute to the achievement of the general aims of national education in Turkey" [27] (p. 13). The approach adopted for religion education is described as follows: "When developing the curriculum of ... Religious Culture and Ethics, knowledge based on science and research about Islam and other religions is prioritized and knowledge that is not contained in real religious sources is avoided. In regard to knowledge about Islam, an approach that is centered on the Qur'an and the sayings of Prophet Muhammad ... without any reference to a specific religious movement is adopted and root values that embrace basic religious assumptions on Islam are emphasized. These values about faith, worship, and ethics are selected because they all share common points related to the Qur'an and the sayings of Prophet Muhammad. The ultimate aim is to make the learners correctly informed about religious, cultural, and ethical values. All religious and ethical values consistent with this approach are included in the curriculum. However, special attention is paid to avoid having a doctrine-based instruction" [27] (p. 19).

The program defines itself as beyond any specific religious movement or singular religious orientation. Instead, it reflects all of them. This model can be understood in two ways: as a "uniting model" or as a "plural model". On the first model, it is the essence of religion that should be taught, not details about various religious trends. In other words, children with distinct religious orientations may take the course, but it should be emphasized that these orientations are merely different distinct understandings of the same religion. On the plural model, in contrast, the course should mirror the society. In other words, it should not only deal with various orientations within the same religion but also address different religions and their worldviews and ethical understandings [28] (pp. 32-40).

According to the interpretation adopted in Turkey, religious education should focus on common points taught based on the major sources of the religion. Such a course aims to inform about rather than popularize religion. While the course teaches students about different understandings and practices of religion, it largely ignores differences between religious movements within the same religion.

It is this approach that tends to be the focus of criticisms against education in religion in Turkey. The primary criticism against the approach is that it only deals with common points and excludes discussions of difference, which means that it ignores the plurality of interpretations of religion. Another related criticism is that this model fails to prepare learners for the religious differences they 
will encounter in their daily lives. This situation does not encourage the values of mutual respect and tolerance and therefore, the course is not consistent with real life experiences [29] (pp. 580-581).

Bilgin agrees with these criticisms: "Is it not more appropriate for children to acquire the experience of being aware of the differences in their classroom, given that they live in a country with people of different religious orientations and cultures, instead of having them educated in separate classrooms where students with the same religious orientation and cultures attend the same class?" After asking this question, Bilgin proposes a solution: "The programs of elementary-school classes can be organized focusing on the common beliefs and behavioral rules of all religions without dealing with details of different religions and religious orientations. The programs of older students, on the other hand, again include those with different religious beliefs, but in this case [different] religions and religious movements [should be] introduced as topic of study and the differences resulting from these distinct religious orientations emphasized. Thus, it is further emphasized that believers attempt to achieve the same goal using different ways and that one needs to be respectful of such differences" [30].

The religious-education model implemented in Turkey has been criticized as ineffective for its failure to address different religious orientations. In Turkish culture, different religious orientations are not perceived as distinct religions but as different interpretations of the same religion. Therefore, there are no sharp borders among these religious orientations, and this is the primary rationale for ignoring them in the current program. However, although religious movements within the same religion may be merely different ways of interpreting the same religion, ignoring the differences between them may well be problematic. The program as it is currently implemented has another characteristic that is closely related to changing global conditions. This is that this program addresses other religions. This condition is a prerequisite for being tolerant of, informed about, and respectful toward different religions as a prerequisite for universal-mindedness [29] (pp. 581-582).

Specifically, the program states that "the objectives are to provide students with scientific knowledge about religion and ethics [and] to provide them with related knowledge, skills, attitudes, values, awareness, and concepts following student-centered techniques" [25] (pp. 6-8).

The other objective mentioned in the program is "to inform younger generations about and promote their consciousness of religion". In other words, the course aims at providing the students with a knowledge base and skills that they will employ throughout their lives. These objectives are attempted through a constructivist and student-centered approach. According to this approach, students should achieve these objectives themselves. Therefore, both the similarities and the differences between different religious movements are emphasized. In this regard, the program is consistent in terms of its religious and educational premises [29] (p. 582).

According to a classification recently developed by Grimmitt and Hull, religious education falls into one of three types [31] (pp. 24-52): learning religion, learning about religion, and learning from religion [32] (pp. 1-8). Religious education in Turkey today falls into the first of these categories, though historically all three approaches have at one time or another had a place in the educational system. Historically, Muslim societies have not had a sharp distinction between state and religion, and religion has therefore always had a prominent place in education. In the Ottoman Empire, for example, education had a completely religious character. Madrasas, the universities of the day, were responsible for education, and all of the disciplines they taught had a religious character. This began to change with the introduction of a series of new educational programs after the declaration of the Tanzimat reforms in 1839. New schools were established to carry out these new education programs. But even then, courses on religion were included in the curricula of these schools, and education in the empire and subsequently in Turkey has continued to have a religious character until recent times. Nevertheless, over time, the negative consequences of the "learning religion" approach have caused it to gradually lose ground, and today the "learning from religion" approach has largely replaced it [33].

Although there are indications that all three approaches have some degree of impact on the way religious education is carried out in Turkey, it seems that the learning from religion approach has 
been adopted as the basic educational philosophy for religious education in the country. The primary indicators of this are as follows: Consistent with the major characteristics of the learning from religion approach, courses on religion are regarded as a part of other general education courses instead of having a separate position in the program.

Another characteristic of the learning from religion approach is that courses on religion contribute to the development of students. In line with this, courses on religion in Turkey have the objective of contributing to the students' personal, social, and cultural development.

The other major feature of the learning from religion approach is that students should establish their own ideas through interpreting and making sense of knowledge they acquire. Similarly, courses on religion in Turkey aim at educating students who are questioning, have a critical attitude, and produce information [29] (pp. 582-584).

Currently, religious-education courses begin in the fourth grade of elementary school and continue throughout middle and high schools. From the fourth to the eighth grades, classes consist of two hours per week. At the high school level, there are also two hours of class per week. We can say that this class is not considered an Islamic educational class. It is an informative class that addresses religious culture and general moral principles through a curriculum that includes information about different religions. However, Islam is the main emphasis of the curriculum because the majority of pupils are Muslim [34]. The curriculum addresses both multiculturalism and national issues [27]. The existing curriculum expresses the secular nature of the state and the inclination of the curriculum's authors [35].

A student who graduates from high school will have received eight continuous years of religious education. The textbooks for each level are prepared and approved by the Ministry of Education. In Turkey, the state controls and inspects the religious-education curriculum and textbooks. One of the main service units of the Ministry of Education is named the General Directorate of Religious Education (Din Öğretimi Genel Müdürlüğ̈̈), and it is this directorate that prepares the religious-education curriculum for elementary, middle, and high schools in Turkey [36]. All textbooks contain five main themes [37]: 1. The major world religions; 2. The history of Islam and the life of Prophet Muhammad; 3. The ways to perform Islamic rituals; 4 . The role of religion in Turkish history; 5 . Islamic ethics and good manners [15].

In 1995, Necmettin Erbakan, the first Islamist prime minister of Turkey, came to power. But he was removed from his position in what has become known as the "postmodern coup" of 28 February 1997. After the coup, the state proclaimed a fight against fundamentalism and declared that secularism was the basis of the state and the surest defense of peace and order. As part of this, the system of public education was once again restructured. Elementary school and middle school were folded together into eight years of primary school, thus dealing a blow to Imam-Hatip middle schools, which either closed or else remodeled themselves as high schools [15]. A new education-reform bill was introduced, as the result of which Imam-Hatip graduates lost their rights to enter employment in several state bodies, including the police force and the army. Furthermore, as graduates of nominally "vocational" schools, they were effectively barred from studying at the university level in any field except for that in which they had received training - that is, those who wished to pursue a higher degree could only do so in the field of theology. As a result of these changes, the number of students of the Imam-Hatip Schools dramatically dropped from 600,000 to 50,000 [38].

\section{The Current Situation of Religious Education (Golden Age of Religious Education)}

During the elections of 2002, things began to change. A new party, the AKP, won the elections on a platform of greater cooperation with the West, membership in the European Union, and coexistence between Islam and democracy. The party began to scale back the strict secularism that had been implemented after the 1997 coup and focused instead on taming inflation, deregulating the economy, and reducing the state sector. With its openness to foreign investors and its support for liberalism and democracy, the AKP presided over a period of rapid economic growth [15]. The party believed that the decisions of the past had damaged religious education in Turkey. 
From 2002 to 2011, the AKP government pursued noteworthy reforms in line with its push for European Union membership. In this process, The AKP government has made significant progress in the field of human rights. It has provided a wide range of freedom to all sections of society and to both religious and non-religious groups. From 2012 and onward, however, the AKP began to be criticized seriously for its statements and policies on a broad spectrum of political, regional, human-rights, and religious matters. There have been increasing concerns that the party is now pursuing a politically exclusive system, one rooted in a Sunni Muslim religious national identity [39] (p. 5-6). However, no significant changes took place in religious education until 2012.

In March 2012, a new law once again restructured the Turkish education system. The new system, popularly known as " $4+4+4$ ", once again split compulsory public education into three periods, with four years of education at the elementary-, middle-, and high-school levels [40]. The rationale for this was to allow students and their families to choose whether they wanted to study at a general-education middle school or a technical or vocational school of some sort, including religious "vocational" Imam-Hatip middle schools. This new system thus ushered in something of a golden age for religious education. After being shut down as part of the strict regulations implemented after the 1997 coup, Imam-Hatip middle schools were once again reopened [29] (p. 39).

Under this new system, which took effect in the 2012-2013 school year, courses on the Qur'an and the life of Prophet Muhammad are offered as electives for middle- and high-school students. The Ministry of Education may also prepare elective courses on Christianity and Judaism [29] (p. 40). The Religious Culture and Ethics course is still compulsory and continues to be taught on a non-confessional model from fourth grade to the end of high school for two hours a week.

Since 2012, when Imam-Hatip middle schools were opened, the total number of pupils aged 10-14 studying in these schools has risen to seven hundred thousand students (out of a total of 5.5 million middle-school students). In Imam-Hatip high schools, there are six hundred and fifty thousand students (out of a total of 5.7 million high-school students). The government has also increased religious-education teaching at regular state schools, some of which have been converted into Imam-Hatip schools. Although the number of Imam-Hatip schools students make up only 11 percent of the total high-school population, they receive 23 percent of funding (roughly 1.5 billion dollars) - double the amount spent per pupil at mainstream schools. Despite this level of support, Imam-Hatip schools have lower success rates than other regular state schools [41].

This process also produced important developments in higher religious education. The number of faculties of theology has increased from twenty-five to eighty and the number of students has increased from three hundred to fifty thousand. The teacher-training programs for religious-education teachers that were formerly located within faculties of education have been transferred to faculties of theology, which are now the only faculties to provide teacher training in religious education [16] (pp. 27-30).

Ziya Meral summarizes the contents of the compulsory religious-education textbooks in Turkey for the US Commission on International Religious Freedom as follows: "Currently, the religious freedom and religious education picture in Turkey is complex. There is now more religious freedom for both Muslims and non-Muslims than in any other era of the republic. But political polarization, the government's policies and actions since 2012, and a deep-seated culture war in the country are creating new grievances. Non-religious Turks, and those not from classically understood Sunni Muslim traditions, feel that they are being pressured to adopt or adhere to a particular political ideology rooted in the Hanafi school of Sunni Islam. Within a context of fierce political competition, deep mistrust between different communities, and non-compromising attitudes of both the government and political opposition parties, the issues of religious freedom and religious education have become deeply politicized. With the political changes in Turkey over the last decade, this strong, state-enforced secularist vision has been weakened; however, challenges remain. Previously, pious Muslims complained that state-regulated religious education was imposing a secularist version of Islam. Now, with the AKP government's perceived push of Sunni Muslim beliefs and practices, less-religious Turks and non-Sunni Muslim minority communities, such as Alevis, argue the government's interference in 
religious education is imposing a religious agenda. In addition, there have been reactions from within Sunni Muslim communities that the government should not use state channels to endorse Islam" [39] (p. 7).

The most common criticism in recent years is that the government is imposing its ideology on students through religious education. It is natural for the political power to address the expectations of its supporters. However, it is different when the situation comes to religious education. Religious education must not simply be a conduit for the ideology of political power; it must be based on scientific methods and it must be centered on values education.

\section{Values Education or Religious Education?}

Influenced by the philosophy of the Enlightenment, religion is considered as opposed to reason and rationality; it is seen as something that is separate from the political sphere and that takes place in people's private lives. This is the context from which secular theories emerged. For instance, Casanova distinguishes three different directions that the theory of secularization has taken: "the differentiation of the lay sphere from religion, secularization as a decline of religion (practices and beliefs), and secularization as the privatization of religion into its own sphere. This paradigm accepts the differentiation within Western society, but it shows that religious institutions keep playing an important role, above all within civil society. This role is not necessarily opposed to the process of secularization" [42]. However, the development of secularism in Turkey is different from that in the West. From the beginning, the modernization and secularization movements in Turkey were largely inspired by France, and thus French laïcité has provided a substantive model for Turkish secularism [14]. The French term "laicism" (Turkish: laiklik) is commonly used by Turks when referring to secularism in their country. In Turkey, secularism has no social or historical basis; it is carried out by the hand of the state, imposed in a top-down fashion, and it only emerged as a result of external dynamics [14]. For this reason, the secularization process was never fully successful, for the state completely excludes Islam, which has always been characteristic of Turkish society [43].

Walton addresses two types of secularism in Turkey: liberal secularism and illiberal or laicist (Jacobin) secularism. It is because of the socio-political history of this region that Turkey has embraced a more laicist secularism, as compared to a more passive secularism [14]. As mentioned in the introduction, anti-religious strict secular practices gave the impression that Islamists were against secularism. When Turkey's secular historical process is analyzed, it is seen that the Islamists are not anti-secularist. According to Büyükkara [44], it is not necessary to define conservatives or Islamists (the majority voters of AKP) as anti-secularist. Perhaps the AKP is not so much anti-secularist as it is anti-Kemalist. Kemalism "has tended to be an authoritarian state ideology to stamp out religious and ethnic differences in the name of Enlightenment values" [45] (p. 60). As a result of Kemalism's adherence to assertive secularism, Kemalists were forced to create a "modern Turkish identity" by excluding religion. However, conservatives or Islamists embraced Islam as a part of Turkish identity and culture, and hence did not reject religion (or religious culture) on Turkey's path to "modernity" [43].

The basis of secularism is the definite separation between the public sphere and private life. Religion is to be part of private life, while the public sphere should stay neutral on religious matters. The problem is that secularism is not neutral in Turkey. Especially in the early period of the republic of Turkey (1923-1950), the state completely rejected Islam and failed to meet the demands of different segments of society. The Turkish republic witnessed seventy of such secularity. In this process, there were different approaches to religious education. First, it was mandatory; then, it was elective (on a confessional model); and then it was mandatory again (again on a non-confessional model). This is where Turkey is today. The presence of religious education in state schools is the result of Turkey's historical experiences [46] (p. 108).

Professor Cemal Tosun, one of the leading scholars of religious education in Turkey, has argued that religion has social, cultural, philosophical, universal, and legal essentials that need to be taught in religion courses in a secular country $[17,47]$. 
"One of the basic functions of education is to reveal and support the skills of all individuals and to meet basic demands consonantly.... Religion is necessary to meet the need of faith, which is one of the important needs of human beings. According to these assessments, a sense of religion is an instinctive and ongoing ability and need. It is an ability because every human being has tendency and ability to believe in a Supreme Being. It is a need in the sense that religion and faith are the features that make a human being a human being. This religious sense of the human being is infinite. But by hook or by crook he satisfies himself. What is expected from this education is to prevent people from this random or faulty satisfaction and to enhance the physical and spiritual ability of individuals. To separate the religious need and feeling from the other needs or to disregard them is against the aims of education. The other important subject that should not be disregarded is that the human being is a social essence. Another vital task expected from education is to socialize new generations. Socialization can be defined as 'to enable people to comply with the society that they live in'" [46].

Religious education can help people to socialize in two ways: first, by providing background experience to those who want to attend religious activities by teaching them necessary knowledge, attitudes, and behaviors; second, by providing positive appreciation and better comprehension to those who do not attend religious activities done by others [17].

Education is meant to convey to new generations those aspects of a society's cultural heritage that are not obstacles to its advance. In every society's cultural heritage, there are of course concepts that come from religious knowledge. Religion is also a decisive element in a nation's or society's identity. Religion is as important a part of culture as language and history. Moreover, it affects other cultural elements as well. Consequently, it is necessary to teach about religions, both because they are an element of culture and because they are an affective factor in human life. Otherwise, new generations will have identity problems and they will not be able to appreciate and comprehend the cultural values of their society, which will result in cultural degeneration [46,47].

As stated earlier, obligatory religion courses in Turkey were not put into the curriculum to insist on a specific sect or belief. The Religious Culture and Ethics course was designed within the frame of basic Islamic values and it encompasses all sects, leaving nothing for misinterpretation. This education program aims to provide students true knowledge about religion and morality and to enhance their basic skills, while contributing to the general aims of national education (service and citizenship education) [17,47]. When the Religious Culture and Ethics teaching program was being developed, research-oriented information about Islam and other religions was used and all inconsistent information was removed. The resulting approach was centered on the Islamic sources of the Qur'an and Sunna. The basic values of Islam and related issues were given high priority. Care was paid to present values related to faith, prayer, and morality on the common ground of the Qur'an and Sunna [27]. The main aims of the course are to provide useful and true information about religious, cultural, and moral values (a cognitive, information-oriented approach). The course teaches all religious and moral values that are appropriate for this approach but takes care not to insist on doctrine, especially doctrine based on a specific sect [28] (pp. 32-40).

As noted above, Turkey has opted for compulsory religious education as a result of historical experience. But non-confessional compulsory religious education does not meet the expectations of many religious people in Turkey. For this reason, religious people tend to prefer to send their children to Imam-Hatip schools, whose numbers have accordingly been on the rise in recent years.

Meral says, "The books used in the Religious Culture and Ethics class today are a clear improvement from those used in years past. They contain no derogatory statements about minority communities or non-Muslim world religions. The substantial new sections on Alevi traditions are welcomed improvements. The provisions on religious freedom and the importance of freedom of worship, thought, and conscience are commendable. Similarly, the sections on different interpretations of religions and the importance of respecting and understanding other Muslim denominations are 
noteworthy [39] (p. 19). The basic criticism for the new books is that despite these positive changes, they teach Muslim culture and Islamic religious education in a way that is deeply shaped by the officially sanctioned and historically dominant reading of Islam in Turkey" [39] (p. 20).

Other criticisms about courses on religion in Turkey, as expressed in the decisions of the European Human Rights Court and State Council, center on the charge that these courses are based on only one religion and on a single religious orientation toward that religion. However, if these courses are closely analyzed, one sees that they are not based on only one religion. Although knowledge about Islam is regarded as an objective for the courses on religion, the reasons for it are explicitly explained. More specifically, it is stated that Islam is the religion that has had the deepest impact on the language, culture, arts, and traditions of the country. In learning about Islam, students are given knowledge about these effects. Thus, the religious education in Turkey includes some of the basic tenets of the "learning about religion" approach, mentioned above [29] (p. 584).

Another criticism is that the values education in religion courses is inefficient. There is values education in the religion-course curriculum, but this training is theoretical and didactic rather than practical in application. One teacher stated in their research that the program's content was insufficient and that they did not undergo any training on values education [47].

The relationship between religion and morality and values has been controversial throughout history. For example, according to Locke, who saw the basis of morality as non-religious, the basis of moral knowledge is the mind [48] (p. 71). According to Kant, we can reach real moral knowledge with a pure practical mind [49] (pp. 34-37). According to Moore, people can discover good or bad morality through intuition [48] (p. 54); and according to Rousseau, emotions apart from selfishness are the source of morality [50] (p. 152). According to those who argue that the basis of morality is religion, religion determines what should and should not be done, and also religion determines the moral good or bad [51] (p. 4). People cannot decide independently of God. God declares orders and prohibitions with his apostles and his holy books [52] (p. 304). God has revealed to people how to believe, how to behave, what is good, and what is not good. For example, Ghazali believes that the way of human morality is through religious rules and that this morality is based on the Qur'an and Sunna [53] (pp. 253-258). The assessment of moral behavior as good or bad is a form of value judgment. Value judgments also include statements that decide what is right and wrong. We use these value judgments in deciding whether a behavior is good, beautiful, right, or wrong. Generally speaking, "all moral provisions are a judgment of value" [54] (pp. 27-31). Moral value is a concept that is hard to define objectively. The question "What is moral value?" is the oldest, most fundamental, and most discussed problem of moral philosophy. In order to find an objective basis for moral values, it is necessary to find principles that will be accepted by everyone about what is "good" and "bad" [55] (p. 18). These debates are also reflected in the distinction between religious education and values education. In the West, the impact of religious institutions on society and the state has been lost due to the Enlightenment period and secularization [56]. In this period, values education was advocated in place of religious education in schools [57]. In this way, there has been an effort to separate religion and morality from each other in order to provide an autonomous moral structure rather than a passive commitment to authoritarian moral principles [58].

In Turkey, between the years 1974 and 1982, an ethics course which did not take religion as a reference was included in the national curriculum [59] (p. 263). In 1982, religious and moral education were combined into a single course. After this, ethics education began to take religion as a reference. As mentioned above, the effect of ethics education on students remained limited [60].

Despite the many developments that have taken place under the AKP, including modifications to the compulsory religious-education program and an increase in the number of Imam-Hatip schools, popular expectations for religious education have not been met. In Muslim societies, the most basic expectation of religious education is the development of individual and social morality. But even in the "golden age" of religious education, such things as prostitution and child abuse continue. The number of detainees and convicted people in prisons has increased, as has drug use, and the homicide rate 
has risen fivefold [61]. In addition, the level of religiosity in Turkey has decreased and the number of atheists and "deists" has increased [3].

These trends show that religious education based only on knowledge without prioritizing values education is not enough. Both religious and moral education should be given equally.

In general, in Muslim countries, particularly Turkey, the fundamental problem in religious education is that the only priority is memorizing knowledge. This is problematic for values education, and it also means that religious education fails to meet people's expectations for religious education, as mentioned above. Before religious education, values education must be taught to students. Religious education cannot be successful without values education.

In Turkey, school books treat values education as a process in which the child is advised what he or she should or should not do and is taught what is right and what is wrong. It is often ignored that children's universal, cultural, and individual judgments will develop in the context of behavior, cognition, and emotion. Virtues that need to be focused on, like empathy, sympathy, and respect, are being neglected. However, when children's cognitive, social, and emotional development is taken into consideration, it is more likely that the children will acquire the elements of being good and righteous by questioning, empathizing, and respectfully developing their existing internal potentials [62].

For this reason, it is important for morality to come before religiosity. In this way, the prevalence of formal (superficial) religiousness, which is one of the fundamental problems of the Islamic world, can be reduced. Religious education that has political aims does not contribute to social peace. Religious education that does not prioritize values education cannot succeed. Religious education should be based on individual and social freedom and should emphasize correct religious knowledge, a culture of coexistence, and values education.

\section{Conclusions}

Turkey is a unique country in the modern world. It is steeped in Islamic history, yet it strives to be a modern secular culture. Turkey is also a good example, as it strives to be both secular and tolerant, not only of other faith traditions but also of Islam, which remains a powerful cultural force within a culture striving to become secular. Within this context, the historical process of secularism in Turkey may give researchers new inspirations [43].

Over the course of Turkey's history, the state's role in religious education has changed significantly. In the periods when the state did not take responsibility for offering religious education, Turkey suffered great hardships. As the result of these experiences, Turkey concluded that the state should take responsibility for religious education.

The Turkish state has shown more interest in religious education since 2012. Under the education system that came into force in March 2012, there are religious elective courses, such as the those on the Qur'an and the life of Prophet Muhammad, but the addition of these new courses does not mean that the Religious Culture and Ethics course has no place in the curriculum. This course remains important because its content addresses all people and it helps prevent students from becoming alienated from their society and world by offering them objective information about their own and other religions.

It is important for the state to take responsibility for religious education and to provide correct knowledge and ensure social solidarity. The state should educate its citizens about the religious and cultural life of their community. Otherwise, people will have to actively choose to study religion as an elective in schools; and of those who do not, some may choose to study religion privately from other sources, but many will likely never study religion at all. Such a state of affairs endangers social peace in a multicultural world. To prevent this, and to establish social peace, the state must take responsibility for religious education. However, this responsibility must be fulfilled by a religious education that prioritizes values education, for only religious education based on values rather than ideology can provide the desired social peace.

The results of a failure to do so are clear. Even in periods when the Turkish state fully encouraged religious education, social problems did not decline as expected [3]. This is because religious education 
alone, without an emphasis on values education, can never succeed. The results of the research presented above show that such an educational model has no contribution to social peace.

In this context, regarding religious education and moral education in Turkey, I offer three final points by way of a conclusion. First, it should be ensured that the sections in textbooks on different faiths be written by experts from those religions and that material on those faiths be taught in the way those religions see themselves; different faith traditions should be explained from the perspective of those faith traditions rather than from a Muslim perspective. Second, religious education should not be a source of polarization in society. Religious education should not become an ideological tool in the hands of political power. Finally, values education must be done before religious education, and religious education must follow values education. Moral awareness is required to orient progress in science and technology toward the welfare of mankind; common values are required to unite human beings and to rediscover the traditional values that are currently in general decline. Teachers pass values to their students both consciously and unconsciously through their conduct in and out of the classroom. Therefore, the need for a consciously planned values-education program as part of the formal curriculum is clear. Students will face complex situations where they need to make decisions involving values. They should be helped to develop the ability to make proper choices in such situations through values education. The increase in juvenile delinquency in society today is a youth crisis, a crisis among young people who are engaged in the process of personal growth. In such a situation, values education assumes a special significance. Values education awakens curiosity, develops proper interests, attitudes, values, and the capacity to think and judge for oneself, and helps to promote social and natural integration [63].

Moreover, values education can teach students how to be part of their diverse world by emphasizing pluralism and inclusiveness, especially in terms of cultural values, as part of more universal values. A good and virtuous person, someone who is respectful and honest, is a good and virtuous person whether he or she practices a religion or not.

In multicultural and multi-religious societies, values education should be prioritized along with religious education. Theological differences between religions or negative expressions in religious texts about other religions have an alienating and parsing effect, but universal values have a unifying effect. Therefore, I want to conclude this work on the relation between religious education and values education in a secular age by quoting John Ruskin: "There are many religions, but there is only one morality".

Funding: This research received no external funding.

Conflicts of Interest: The authors declare no conflicts of interest.

\section{References}

1. Zengin, Z.S. Tanzimat Dönemi Osmanlı Örgün Eğitim Kurumlarnnda Din Eğitimi ve Öğretimi (1839-1876); MEB Yayınları: İstanbul, Turkey, 2004.

2. Aytulu, G. Ateist Sayıs1 Artiyor Mu? Hurriyet Gazetesi 2015. Available online: http://www.hurriyet.com.tr/ kelebek/hayat/ateist-sayisi-artiyor-mu-29876400 (accessed on 22 October 2018).

3. Kulat, M.A. Türkiye'de Toplumun Dine ve Dini Değerlere Bakışı; MAK Danışmanlık: Ankara, Turkey, 2017.

4. Hiro, D. Inside Central Asia: A Political and Cultural History of Uzbekistan, Turkmenistan, Kazakhstan, Kyrgyzstan, Tajikistan, Turkey, and Iran; Overlook Duckworth: New York, NY, USA, 2011.

5. Daver, B. Secularism in Turkish Republic. Available online: http://dergiler.ankara.edu.tr/dergiler/42/451/ 5082.pdf (accessed on 8 August 2018).

6. Szymański, A. Secularism in Turkey-What Is It All About Today? In Proceedings of the ECPR Joint Sessions, Nottingham, UK, 25-30 April 2017.

7. Toprak, B. Islam and Political Development in Turkey; Brill: Leiden, The Netherlands, 1981.

8. Jones, E. The Conflicts of Secularization and Islam in Turkey. Master's Thesis, Salve Regina University, Newport, RI, USA, 2010. 
9. Kesgin, S.P. The Evolution of Political Islam in Turkey: Comparing Party Programs of Islamicí Parties in Government; Graduate Faculty of the University of Kansas: Lawrence, KS, USA, 2009.

10. Malik, Y. The Rise and Fall of Secularism in Modern Turkey. 2017. Available online: https://www. globalvillagespace.com/rise-fall-secularism-modern-turkey/ (accessed on 15 October 2018).

11. Cizre, Ü. Secular and Islamic Politics in Turkey: The Making of the Justice and Development Party; Routledge: London, UK; New York, NY, USA, 2008.

12. Sheikh, M.; Wæver, O. Comparative Secularism across Europe and the Middle East. Presented at the Annual Meeting of the International Studies Association, Hilton Hawaiian Village, Honolulu, HI, USA, 1-5 March 2005.

13. Kramer, H. A Changing Turkey: The Challenge to Europe and the United States; Brookings Institution Press: Washington, DC, USA, 2000.

14. Kuru, A. Dynamics of secularism: State-Religion Relations in the United States, France, and Turkey. Ph.D. Thesis, University of Washington, Seattle, WA, USA, 2006. Unpublished.

15. Alasania, G.; Gelovani, N. Islam and Religious Education in Turkey. IBSU Sci. J. 2011, 5, 35-50.

16. Genç, M.F. Avrupa ve Türkiye'de İlahiyat Fakülteleri Lisans Programları (İspanya, Bosna Hersek, Hollanda, Belçika ve Almanyadaki İlahiyat Fakülteleri İle Bir Karşılaştırma). Din Bilimleri Akademik Dergi 2013, 13, $27-45$.

17. Genç, M.F. What Should Be the Positıon of The State in Relıgıus Educatıon, An example from Turkey; Oğuz Kutlu Educational Sciences, Ed.; Akademisyen Yayınevi: Ankara, Turkey, 2018; pp. 107-113.

18. Doğan, R. 1980'e Kadar Türkiye'de Din Öğretimi Program Anlayışları (1924-1980). In Din Öğretiminde Yeni Yöntem Arayışları, Uluslar arası Sempozyum Bildiri ve Tartışmalar (İstanbul 28-30 Mart); Milli Eğitim Bakanlı̆̆ı Yayınları: Ankara, Turkey, 2003.

19. Yürük, T. İlk ve Orta Öğretimde Din Öğretimi: Din Dersleri; Din Eğitimi El Kitabı; Grafiker Yayınları: Ankara, Turkey, 2012; pp. 105-138.

20. Hamdullah, S. CHP Yedinci Kurultay Tutanağı; Ulus Basımevi: Ankara, Turkey, 1948.

21. Öcal, M. İmam-Hatip Liselerinde Din Eğitimi; Altaş, N., Köylü, M., Eds.; Din Eğitimi; Gündüz Yay: Ankara, Turkey, 2012.

22. Ayhan, H. Türkiye'de Din Ĕ̆itimi; M.Ü.İ.V. yay: İstanbul, Turkey, 1992.

23. Bilgin, B. Eğitim Bilimi ve Din Eğitimi; Gün Yay: Ankara, Turkey, 2007.

24. Altaş, N. Türkiye'de zorunlu din öğretimini yapilandiran süreç hedefler ve yeni yöntem arayişlari. Dini Ara 2002, 145-168. [CrossRef]

25. T.C ANAYASASI 1982. Available online: https://www.tbmm.gov.tr/anayasa/anayasa_2016.pdf (accessed on 12 September 2018).

26. Altaş, N. Ortaöğretimde Din Eğitimi. In Din Eğitimi; Altaş, N., Köylü, M., Eds.; Gündüz Eğitim ve Yay: Ankara, Turkey, 2012.

27. T.C. Milli Eğitim Bakanlığ1 (MEB). Din ğretimi Genel Müdürlüğ̈̈, Ortaöğretim Din Kültürü ve Ahlak Bilgisi Dersi Öğretim Programı (9, 10,11 ve 12. Sinıflar); Devlet Kitapları Müdürlüğü: İstanbul, Turkey, 2005.

28. Kizilabdullah, Y.; Tuğrul, Y. Din Eğitimi Modelleri Çerçevesinde Türkiye'deki Din Eğitimi Üzerine Genel Bir Değerlendirme. Dini Araştırmalar Dergisi 2008, 11, 32-40.

29. Genç, M.F. History and Current Situation of Religious Education in Turkey. C.Ü. İlahiyat Fakültesi Dergisi 2012, 6, 539-585.

30. Bilgin, B. Mezheper ve Dinlerarası Eğitim ve İşbirliği. Ankara Üniversitesi İlahiyat FAkültesi Dergisi. Available online: http:/ / dergiler.ankara.edu.tr/dergiler/37/779/9962.pdf (accessed on 10 October 2018).

31. Grimmit, M. Contemporary Pedagogies of Religious Education; McCrimmons: Southend-on-Sea, UK, 2000.

32. Hull, J. The Contribution of Religious Education to Religious Freedom: A Global Perspective; Religious Education in Schools: Ideas and Experiences from around the World; IRARF: Oxford, UK, 2001.

33. Genç, M.F.; ter Avest, I.; Miedema, S.; Westerman, W. A conversational analysis of developments in religious education in Europe and Turkey. Br. J. Relig. Educ. 2012, 34, 1-17. [CrossRef]

34. Kaymakcan, R. Christianity in Turkish Religious Education. Islam Christ-Muslim Relat. 1999, 10, $279-293$. [CrossRef]

35. Akbulut, O.; Usal, Z.O. Parental religious rights vs. Compulsory Religious Education in Turkey. Int. J. Minor. Group Rights 2008, 15, 433-455. [CrossRef] 
36. Genç, M.F.; ter Avest, I.; Miedema, S. Religious education in two secular multicultural societies: The Turkish and Dutch case compared. Procedia Soc. Behav. Sci. 2011, 15, 801-805. [CrossRef]

37. T.C. Milli Eğitim Bakanlığı (MEB). İlköğretim Din Kültüre ve Ahlak Bilgisi Öğretim Programı ve Kılavuzu (4, 5, 6 , 7 ve 8. Sinıflar); Devlet Kitapları Müdürlüğü: Ankara, Turkey, 2010.

38. Genç, M.F. 2023 ve 2071 Türkiye'sinde İmam Hatip Liseleri. Eğitime Bakış Dergisi 2015, 11/35, 19-25.

39. Meral, Z. Compulsory Religious Education in Turkey a Survey and Assessment of Text Books; United States Commission on International Religious Freedom. Available online: https:/ /www.uscirf.gov/sites/default/ files/TurkeyTextbookReport.pdf (accessed on 10 October 2018).

40. Gün, F.; Baskan, G. New Education System in Turkey $(4+4+4)$ : A Critical Outlook. Procedia Soc. Behav. Sci. 2014, 131, 229-235. [CrossRef]

41. Butler, D. Special Report: With More İslamic Schooling, Erdogan Aims to Reshape Turkey. 2008. Available online: www.reuters.com (accessed on 15 September 2018).

42. Garcia, V.J.; Ivanescu, C. Religion as social curriculum: Education, values and Islam in Europe. Educ. Pesqui. 2013, 39, 1017-1028. [CrossRef]

43. Sevinc, K.; Hood, R.W.; Coleman, T.J., III. Secularism in Turkey. In The Oxford Handbook of Secularism; Zuckerman, P., Shook, J., Eds.; Oxford University Press: Oxford, UK, 2017.

44. Büyükkara, M.A. Ilımlı Islam tartışmaları zemininde günümüz Türkiyesi'nde laikliğin anlam ve sınırları. Usul 2008, 9, 173-200.

45. Yavuz, M.H. The Case of Turkey. Daedalus 2003, 132, 59-61.

46. Tosun, C. Din Eğitimi Bilimine Giriş; PegemA Yay, 3.Baskı: Ankara, Turkey, 2005.

47. Genç, M.F. Should State Take Responsibility for Religious Education? An Example from Turkey. Available online: https://religiouseducation.net/rea2013/files/2013/07/GENC.pdf (accessed on 8 October 2018).

48. Kiliç, R. Ahlâkı Temellendirme Problemi; Felsefe Dünyası: Ankara, Turkey, 1993.

49. Aydin, M. Kant'ta ve Çağdaş İngiliz Felsefesinde Tanrı Ahlâk Ilişkisi; TDV yay: Ankara, Turkey, 1991.

50. Topçu, N. Ahlâk, Haz, Ezel Ezverdi, Haz; İsmail, K., Ed.; Dergâh Yayınları: İstambul, Turkey, 1999.

51. Kiliç, R. Ahlâkın Dini Temelleri; TDV yay: Ankara, Turkey, 2005.

52. Türkgülü, M. Ahlâkın Kaynağı Tartışmaları ve Ortaya Çıkan Ahlak Telakkileri. Fırat Üniversitesi İlahiyat Fakültesi Dergisi. 1998, 3, 291-310.

53. Şeyh, M.; Sait, Ş. İslam Düşünce Tarihi; Şerif, M.M., Ed.; İnsan Yayınları: İstanbul, Turkey, 1996.

54. Güngör, E. Değerler Psikolojisi Üzerine Araştırmalar; Ötüken Yayınları: İstanbul, Turkey, 2010.

55. Güngör, E. Ahlak Psikolojisi ve Sosyal Ahlak; Ötüken Yayınları: İstanbul, Turkey, 2000.

56. Vessels, G.G. Character and Community Development: A School Planning and Teacher Training Handbook; Praeger Publishers: Westport, CT, USA, 1998.

57. Alexander, K.; Alexander, D. American Public School Law; Wadsworth: Belmont, CA, USA, 1998.

58. Zigler, R. The formation and transformation of moral impulse. J. Moral Educ. 1998, 28, 445-457. [CrossRef]

59. Öcal, M. Cumhuriyet Döneminde Türkiye'de Din Eğitimi ve Öğretimi. Uludă̆ Üniversitesi İlahiyat Fakültesi Dergisi 1998, 7/7, 241-268.

60. Genç, M.F. Öğretmenler Gözüyle DKAB Derslerinde Değerler Ĕ̆itimi; Etüt Yayınları: Samsun, Turkey, 2013.

61. Karabiyik, L. Türkiye'de Sosyal Bozulma Raporu. 2016. Available online: http:/ /ahmetsaltik.net/2016/04/ 18/sosyal-bozulmalar-raporu/ (accessed on 10 October 2018).

62. Metindoğan, A. Değerler Eğitimi Nasıl Verilmeli. 2018. Available online: http://www.egitimreformugirisimi. org/degerler-egitimi-nasil-verilmeli / (accessed on 10 October 2018).

63. Manichander, T. Value Education; Ashok Yakkaldevi: Maharashtra, India, 2016.

(C) 2018 by the author. Licensee MDPI, Basel, Switzerland. This article is an open access article distributed under the terms and conditions of the Creative Commons Attribution (CC BY) license (http:/ / creativecommons.org/licenses/by/4.0/). 